is stated to have a length of 600 miles. It says much for the enthusiasm, if not for the knowledge, of the Daily News correspondent that he places Major Pinto in the "first rank of African explorers."

THE International African Association have received letters from MM. Cambier and Dutrieux down to March I6. They state their intention of remaining at Tabora till the end of the masika, or rainy season, which commonly ceases at the beginning of May. M. Cambier says that he has established friendly relations with the Arabs, and that he has ample resources for the next year without further supplies being sent. $\mathrm{He}$ also advises having forwarded an entomological collection made by Dr. Dutrieux. Though intelligence respecting this unfortunate expedition is remarkably vague, it may be hoped that we shall before long hear of their having done some real work, as they are now well advanced into the interior, have ample supplies, and the proper travelling season before them. The Association's second expedition will probably not be long before they start for the interior, as MM. Popelin and Van den Heuvel were to arrive on May

\section{THE ERUPTION OF ETNA}

$\mathrm{N}$ the night of Sunday, May 25, loud bellowings were heard by the dwellers on the northern slopes of Etna. Towards the morning of the 26 th these increased, and about midday a dense cloud of smoke was seen to issue from the side of the mountain below the great crater, apparently half way between Randazzo and Linguaglossa. This cloud increased, and on the 27 th the mountain was rendered invisible, and an effect like that of an eclipse resulted. A rain of fine black ash, "like
29 at Zanzibar, whither they have been preceded by M. Dutalis, who has already been engaged in a preliminary examination of the River Wami.

M. DE VILLIERS, the new Governor-General of French Cochin China, was Director of the Interior in Algiers under General Chanzy. He is the author of a dictionary of all the Algerian tribes and sub-divisions of tribes. This valuable work was published some years ago at the expense of the French Government.

THE current number of Les Missions Catholiques contains an account by Père Schmitt of a journey to Loango, in Western Africa.

THE new number of the Annales de l'Extrême Orient contains the first instalment of Dr. J. Harmand's "Notes de Voyage en Indo-Chine," illustrated by a map and copies of Khmer inscriptions. This is followed by part of a paper on New Guinea, in which is embodied much information respecting the Karons, the Kebars, and the Amberbaks. There are also some remarks by R. Friederich on the archæology and iconography of Java.

powdered emery," fell for miles around, and was so thick that Capo di Schiso could not be seen from Taormina, a distance of two miles. This black rain continued all day, accompanied by thundering noises from the mountain. No exact information could be procured concerning the position of the centre of disturbance, because no one could approach the new craters. During the night of the 27 th the ashes continued to fall, and "huge fires could be seen looming through the black clouds"-no doubt the reflection of the molten lava on the smoke above it. It was reported in Piedemonte, a village on the north-

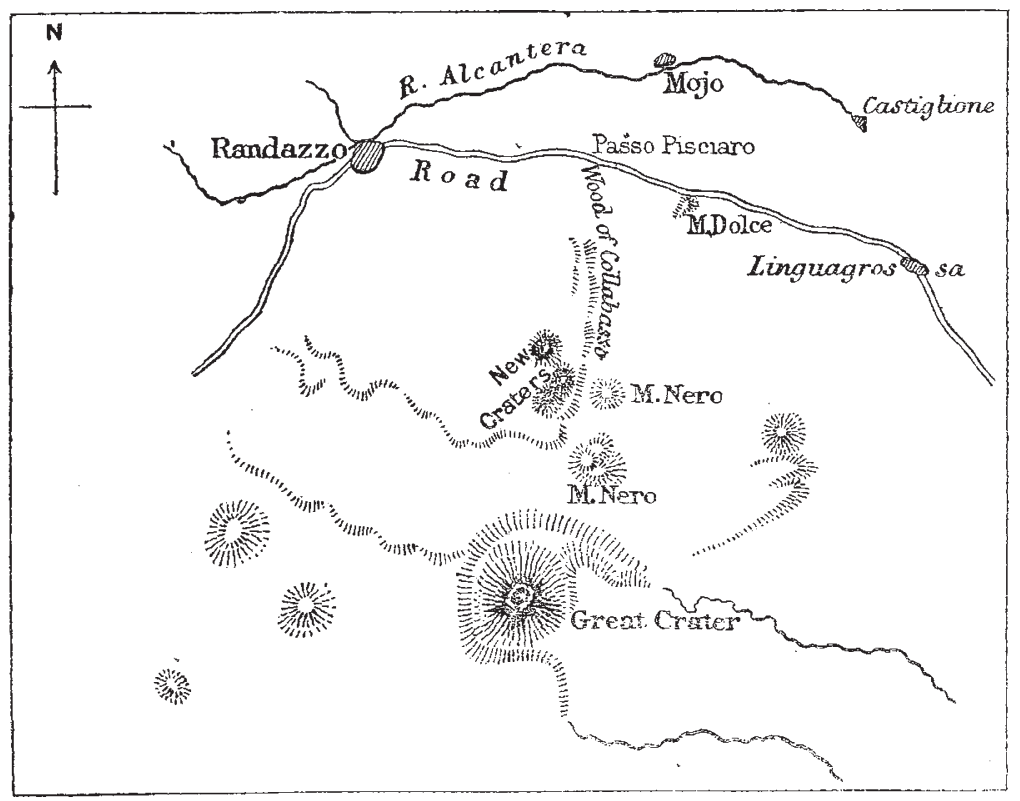

east flanks of Etna, that three craters about a mile apart had opened at the points of a triangle, about six miles above Passo Pisciaro, a posting station nearly midway between Randazzo and Linguaglossa. Lava was said to be flowing in a valley to the north of the Val del Bore. On the 28 th a great stream of lava was seen from Taormina to be descending the mountain in the direction of Randazzo, "while from the new craters great balls of fire were thrown high in the air, and burst into showers of fire like gigantic rockets, accompanied by thundering explosions." On May 29 the lava was still flowing, but the shower of ash was diminished. The facts, as above stated, were witnessed by an Englishman living in Taormina, 800 feet above the sea, at the north-eastern termination of the flanks of Etna, about fifteen geographical miles from the new craters.

Daily bulletins in the newspapers have given us the history of the eruption since May 29 . It is to be regretted that these have not been more concordant. Many times has the lava stream reached the bed of the river Alcantara, according to the telegrams, and often the next day has it been a kilometre distance. A telegram from Rome dated 
June 3 , and published in the Times for June 4, asserted that "the Iava has still half a metre to run before reaching the Alcantara." The previous telegram asserted that the lava had run eleven kilometres from the craters, had rolled into the Alcantara, and had obliterated the Commune of Mojo; while the telegram of the following day made the stream 350 yards from the Alcantara. The fact is, that part of Etna is not thickly populated; distances are often guessed at ; the new craters are not easily reached; and the shower of ashes prevented accurate observation, hence the discrepancies. But by a careful comparison of the telegrams, with the Dettagli sull' eruzione dell' Etna, issued by the Prefect of Catania at frequent intervals, the broadside sheets entitled Guasti dell' eruzione dell' Etna, and the letter written, on May 29, from Taormina, to the Times:-by comparing these with the fine map (scale $=I^{2} \cdot 266$ inch to the mile) of the Italian Stato Maggiore, some of the discrepancies disappear, and a just estimate may be formed of the position of the new craters.

All accounts agree in placing the new craters near Monte Nero, but unfortunately there are two minor cones near together which bear the name of Monte Nero. We are helped out of this difficulty, however by the statement that the new craters are 1,900 metres $(6,232$ feet) above the level of the sea, that the higher of the two Monte Neros is far above this level, while the lower of the two has a little to the west of it a space marked by contours 1,900 metres. Here, accordingly, we shall place the new craters without hesitation.

The great crater, Randazzo, and Linguaglossa, form the three points of a nearly equilateral triangle, within which at present the eruption is completely confined. Linguaglossa is I2 miles from Randazzo, and II from the great crater, while Randazzo is only Io miles from the crater. The new craters are 5 miles from the great crater, $7 \frac{1}{4}$ from Randazzo, 7 from Linguaglossa, 7 from Mojo, $6 \frac{1}{2}$ from the River Alcantara, and 5 from Passa Pisciaro.

The lava has devastated the wood of Collebasso, and has crossed the main road at Passo Pisciaro, destroying the bridge there. Several vineyards have been destroyed, and if the bed of the Alcantara is invaded, the water supply will be cut off from a large tract of fertile land. The lava stream at Passo Pisciaro is about half a mile broad and roo feet in depth. On May 30 it flowed at a rate of one metre per minute.

The last bulletin received to-day (June 6) from Catania dated June I, Io A.M., ends as follows :- "L'eruzione continua al solito. La lava verso il fiume dilatasi sempre, e scende insensibilmente. Stanotte un nuovo braccio investi la vigna di Salvatore Cimino, che quasi distrusse, producendo un danno di circa trentamila lire. La casina prospiciente sullo stradale versa in imminento pericolo." Signor Silvestri of Catania, together with two Germans, have penetrated as near as possible to the new craters. Silvestri, together with Prof. Blaserna of Rome, and Prof. Gemellaro of Padua, have been appointed to report on the eruption, in the interests of vulcanology. It was asserted in the telegram of June 6 from Messina that the stream of lava is only 100 metres from the Alcantara, and that it is advancing at a rate of fifteen metres per hour. Loud rumblings and dense smoke proceed from the new craters.

During the last few days the telegrams have stated that the eruption is diminishing, and that although the lava I : as s.owly progressed, it has not yet reached the Alcantara. So ine curious errors have been propagated in the newspapers. Thus the Times correspondent in Naples, writing under the date of June 2 (published June IO), asserts that "the side on the north-west is rent in two, and the fiery mass is ejected to the height of $I, 900$ metres, or considerably more than a mile." The real facts are that the new craters stand at an elevation of
I,900 metres above the sea; while a fissure which does not extend over even one-half the north-west side of the mountain; has been formed near Monte Nero. It has been asserted that saline mud has recently been ejected; also that the craters emitted on June 2, 450 cubic metres of lava per minute; also that the principal lava stream has a front of 800 metres, and that it has flowed for six or seven miles, But in regard to any exact statements, it will be preferable to wait for the report of Professors Blaserna, Gemellaro, and Silvestri ; or at least for the very detailed account of the eruption, which is sure to appear in the next number of Prof. de Rossi's Bolletino del Vulcanismo Italiano.

G. F. RODWELI

\section{NOTES}

WE understand that by permission of the Statistical Com. mittee of the India Office, the new tide-predicter, which has been constructed for the Survey Department by Mr. E. Roberts (Nautical Almanac Office), will be exhibited at the closing meeting of the Royal Society on the I 9 th inst. The instrument, although not yet out of the makers' hands, is sufficiently complete to show its entire working; in fact, the tide-curves for the year I880 for Bombay and Kurrachee, have been already run off, and the results are now being tabulated for printing. Specimen tide-curves of the Southern Indian, Pacific, and North Atlantic Oceans, the English Channel, and the Mediterranean, will also be exhibited to show the universality of the system of prediction by the instrument.

AMONG those on whom the honorary degree of LL.D. was conferred in the Senate House at Cambridge on Tuesday were Mr. Justice Grove, Dr. W. Spottiswoode, Prof. Henry J. S. Smith, Prof. T. H. Huxley, and Mr. H. C. Sorby,

Prof. HUXLEY has been elected a corresponding member of the Paris Academy of Sciences, in the section of Anatomy and Zoology, in succession to the late Prof, von Baer; and $M$. Schiaparelli in the Section of Astronomy, in place of the late M. Tisserand.

THE death is announced, on the gth inst., of Dr. Moore, who for more than forty years has filled the office of Curator of the Botantic Gardens, Glasnevin, Dublin. He was a native of Dundee, and commenced the study of botany under the late Dr. Mackey, Curator of the College Botanical Gardens, whose place his eldest son, Dr. F. W. Moore, now fills. He was for some time employed on the geological survey of Ireland before he was appointed Curator of the Royal Dublin Society's Gardens at Glasnevin. He pursued the study of botany with great ardour, not only at home, but in various parts of the Continent. Among his works were "Notices of British Grasses," "Irish Hepaticæ," and "Irish Mosses."

IT is proposed immediately to establish a zoological station on the Aberdeen coast, in connection with the natural history laboratory of the University, similar to those already instituted for the Universities of Paris, Vienna, and Leyden. The objects of such a station are:-r. To supply the laboratory with fresh animals for purposes of teaching and research. 2. To enable students to become practically acquainted with natural history, and to afford them opportunities of advanced study and independent research, during the vacations. 3. To afford means for the exhaustive study of the marine fauna. For the establishment of such a station on the smallest possible scale it is necessary to have-(I) A movable shed or house with suitable fittings ; (2) a large fishing boat and a small two-oared boat; (3) nets and dredges; (4) aquaria glassware and miscellaneous apparatus; (5) the services of a fisherman and a boy for part of the year. For the purchase of boats and apparatus a sum of $250 l$. is required, 